\title{
Sexual Systems of Plants in a Brazilian Montane Forest
}

\author{
Monique Perini ${ }^{1}$ (D), Henrique Machado Dias² (D), Sustanis Horn Kunz ${ }^{2}$ \\ ${ }^{1}$ Programa de Pós-graduação em Biologia Vegetal, Instituto de Ciências Biológicas, Universidade Federal de Minas Gerais \\ - UFMG, Belo Horizonte/MG, Brasil \\ ${ }^{2}$ Departamento de Ciências Florestais e da Madeira, Universidade Federal do Espírito Santo - UFES, \\ Jerônimo Monteiro/ES, Brasil
}

\begin{abstract}
In this study, vegetation reproduction has been investigated in order to understand aspects of speciation, structuring and composition of plant communities. Thus, we sought to characterize the frequency of sexual systems from species recorded in seed rain occurring in a tropical rainforest (Atlantic Forest) in Caparaó National Park, Espírito Santo State, Brazil. We collected the seed rain for twelve months, classified and recorded the species for: sexual system; pollination and dispersion syndrome; and fruit type. Then we measured the correlation between these attributes through correspondence analysis. Regarding sexual systems, $71 \%$ were hermaphrodites, $13 \%$ dioecious, and $11 \%$ monoecious. Hermaphrodites are best associated with pollination, dispersion and fruit types, represented by $65 \%$ of data variance. This study may contribute to elaborating management and conservation programs taking into account the interaction of plants with the local fauna.
\end{abstract}

Keywords: seed rain, reproductive ecology, woody layer, Caparaó National Park, Atlantic Forest. 


\section{INTRODUCTION}

Plants' reproductive biology is studied in order to understand aspects of speciation and structuring of plant communities, and consequently to obtain information that supports biodiversity conservation. In this case, the essential aspects of reproductive biology consist of sexual selection, pollen syndrome and resource allocation under the perspective of species evolution. For example, there are predictions that herbivory may influence the evolution of dioecy (Goldberg et al., 2017; Rivkin et al., 2018).

Clarifying plant-animal and plant-environment interactions and their morphological characteristics help in understanding the ecology of the interaction and the evolution of plants with flowers (Peterson \& Kay, 2015). Detection of plant reproductive patterns also helps in understanding the dynamics of gene flow in plant communities, promoting important information about local genetic variability (Barrett, 2013). In addition, knowledge of reproductive patterns provides data that may support conservation of biotic agents for reproductive success of plant species, because 90\% of the Angiosperms in the world need pollinating agents for their fertilization. Hence the disappearance of animal-plant interactions can lead to reductions in population size and local extinctions (Thomson \& Wilson, 2008; Ollerton et al., 2011).

The success of a sexual system in a specific region may be related to association and coevolution with pollinating agents, allowing efficient deposition and pollen removal, which supports irradiation of Angiosperms in evolutionary history (Ollerton et al., 2011). Hermaphrodite species tend to invest in attractive floral resources to pollinator fauna and have effective partnerships with these agents; thus, in the evolutionary scale they would enjoy more time for this investment, with the purpose of avoiding or reducing the development of inbred fruits (Thomson \& Wilson, 2008; Van der Niet \& Johnson, 2012).

Unisex systems (monoecious and dioecious) are considered products of cross-selection to avoid consequences of endogamy. They are usually related to wind pollination or small insects, unlike hermaphrodites that show greater interaction with pollinating insects (Ellis \& Johnson 2010; Rymer et al., 2010).
Some studies have demonstrated positive associations in tropical forests between sexual systems and ecological particularities of individuals such as a habit of woody growth, pollination by generalist insects and fleshy fruits (Matallana et al., 2005; Queenborough et al., 2009), contributing in dynamics, richness and distribution of forest species, and optimizing the reproductive success of individuals in plant communities (Barrett, 2013). Matallana et al. (2005) stated that the quantity of hermaphrodite woody species in tropical forests tends to be larger than unisexual species, being $74 \%$ hermaphrodites, $14 \%$ dioecious and $12 \%$ monoecious; a fact that can be explained due to the greater interaction between plant-animal and plant-environment.

Therefore, our objective was to characterize the interactions and variations in the frequency of sexual systems in woody species registered from seed rain along the Santa Marta Valley, Caparaó National Park, Espírito Santo State, Brazil.

We aim at answering the following questions: 1) What is the frequency of different sex systems of woody species present in seed rain from a Dense Montana Ombrophilous Forest?; and 2) Are hermaphrodite species better associated with ecological attributes such as pollination syndromes, dispersal and types of fruit, as expected for tropical forests?

\section{MATERIAL AND METHODS}

\subsection{Study area}

The study was developed in a stretch of Dense Montana Ombrophilous Forest in Caparaó National Park, municipality of Ibitirama, Espírito Santo State, southeastern Brazil (Figure 1). The Caparaó National Park is a Federal Conservation Unit under full protection located on the border of Minas Gerais and Espírito Santo states, under coordinates $20^{\circ} 19^{\prime}$ to $20^{\circ} 37^{\prime} \mathrm{S}$ and $41^{\circ} 43^{\prime}$ to $41^{\circ} 53^{\prime} \mathrm{W}$. The climate of the region fits in tropical type of altitude/subtropical (Cwb), presenting average annual temperature of $16.8^{\circ} \mathrm{C}$ and average rainfall of 1,284 mm (Alvares et al., 2013).

The study area is located in a valley between two mountain escarpments, which have a main watercourse. Seven permanent plots (sample units) with dimensions of $20 \times 50 \mathrm{~m}$ were demarcated. The plots were distributed along the valley, parallel to the main watercourse, with 

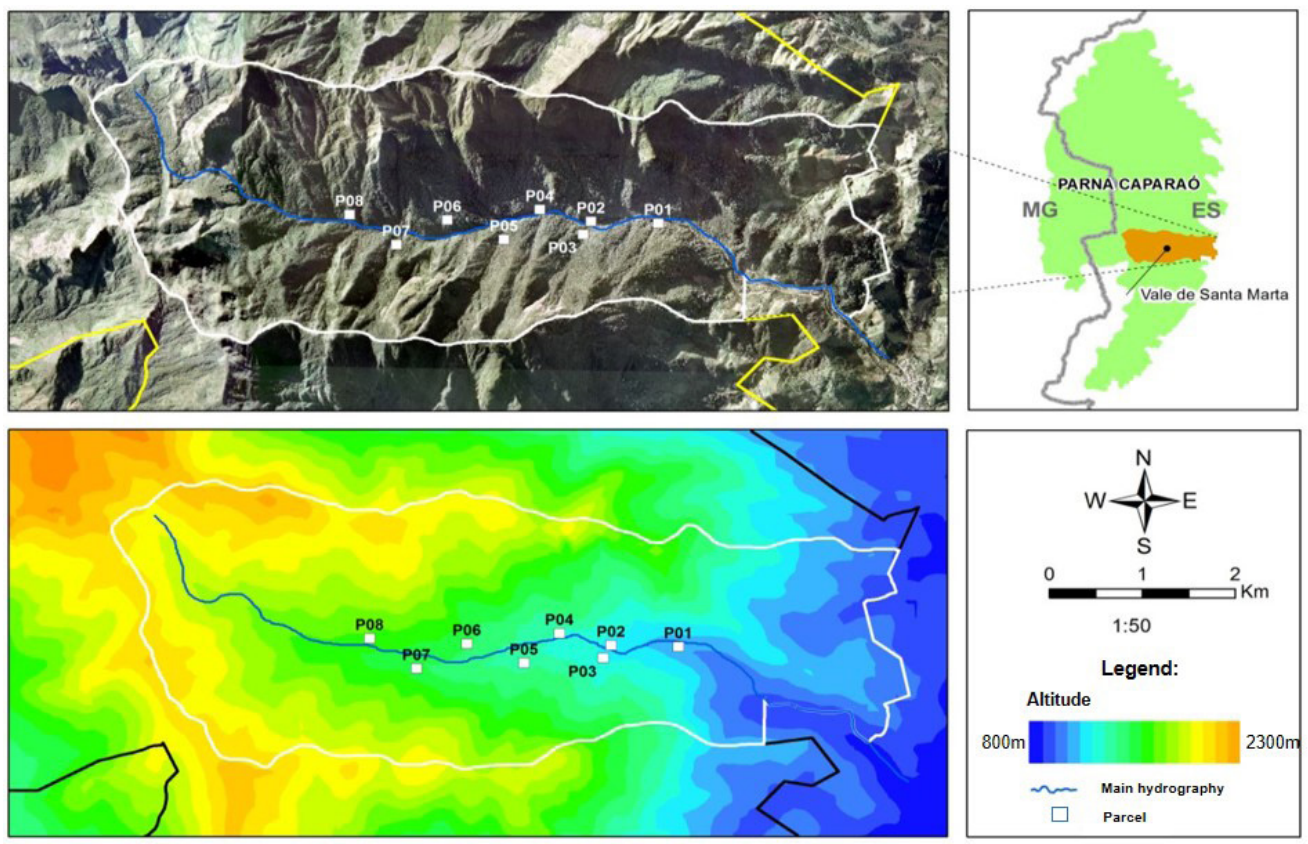

Figure 1. Study area in Caparaó National Park on the border of Minas Gerais and Espírito Santo states, delimitation of the watershed and plot positions. Plots P01 to P07 were used in this study.

altitudinal gradient varying between 1,112 and 1,550 meters. Seven of these plots were used in this study.

In each plot, Perini (2016) allocated 8 collectors for studying the seed rain (which subsidized this study of sexual systems) through the technique of collecting fruits and seeds with fixed collectors, one of the most effective methods to collect propagules. The collectors were arranged in the area in order to obtain a better representation, with an average of 1 collector of $0.25 \mathrm{~m}^{2}$ for each $100 \mathrm{~m}^{2}$ sample area (Clark et al., 2001).

Eight collectors were systematically distributed in each plot with representation of $50 \%$ of the sample unit, totaling 56 collectors in the sampled area. The collectors have a structure of PVC pipes, $2 \mathrm{~mm}$ nylon mesh screens, with dimensions $0.75 \mathrm{~m} \times 0.75 \mathrm{~m}$ $\left(0.5625 \mathrm{~m}^{2}\right)$. They were placed $0.75 \mathrm{~m}$ from the ground (Clark et al., 2001).

\subsection{Characterization of reproductive attributes}

The species registered from the seed rain were classified by Perini (2016) based on the type of sexual system according to the following categories: hermaphrodite, monoecious and dioecious. Hermaphrodite plants are those with androecium and gynoecium in the same flower. Monoecious plants have unisexual flowers of both sexes. Dioecious plants have unisexual flowers, being only male or only female; therefore, in this case there are male and female individuals (Judd et al., 2009).

Data analysis was based on 80 species. It was not possible to identify all seeds at the species level; however, some families are generalists and have the same sexual system in common between species. Some cases were considered indeterminate for sexual system presenting pollination or dispersion syndrome. When the species had more than one type of pollination or dispersion syndrome, we considered two types of syndromes.

In addition to the type of sexual system, species were also classified according to their pollination syndrome, the fruit type and the dispersion syndromes following denominations presented by Judd et al. (2009) as zoochoric, anemochoric or autochoric. In zoochoric dispersion the propagules are dispersed by generalist animals, in anemochoric according to the constancy of winds, and autochoric by the species developing self-dispersal mechanisms, which can be by gravity or even by small fruit explosions (Judd et al., 2009).

For each type of dispersing agent there are suitable morphologies that facilitate the transport of diaspores. They can be attractive to fauna by their colors, smell and/or sweetened pulp. The fruit can be classified based 
on arrangement of its pericarp, which can be fleshy or dry (Judd et al., 2009). According the authors, fleshy fruits are those presenting fleshy or succulent pericarp, or which have seeds embedded in succulent pulp or surrounded by aril, unlike fruits with a dry pericarp.

Regarding the pollination syndrome of species, the nomenclature suggested by Judd et al. (2009) was adopted as being anemophily, hydrophily, entomophily or zoophily. Species pollinated by the wind are called anemophily syndrome, those pollinated by water are called hydrophily, by general or specialized insects, entomophily, and zoophily is characterized by presenting mammals and/or birds as pollinators (Judd et al., 2009).

Taxonomic bibliographies were consulted for characterizing the sexual systems, as well as the ecological attributes. Analysis of exsiccates deposited in VIES, MBML and RB herbarium was consulted when necessary.

\subsection{Data analysis}

A correlation analysis (CA) was used to measure the correlation between types of sexual systems with ecological characteristics, such as the types of fruits and pollination syndromes for the whole studied area, taking into account all sample units of this study using the PAST 3.04 software program (Hammer et al., 2001). The chi-square test was performed $(P>0.05)$ in order to test the significance between qualitative variables such as the occurrence of each type of sexual system, pollen syndrome and fruit type.

\section{RESULTS}

Of the 80 species recorded in seed rain from the Santa Marta valley, it was not possible to identify the sexual system in 5\% (four individuals), while $71 \%$ were hermaphrodites, $13 \%$ dioecious and $11 \%$ monoecious (Table 1).

Table 1. List of woody species registered in seed rain from November/2012 to October/2013 in Caparaó National Park, Ibitirama, Espírito Santo State, with its ecological characteristics of sexual system, pollination and dispersal syndromes, and fruit types.

\begin{tabular}{|c|c|c|c|c|c|}
\hline Family & Species & ङ & 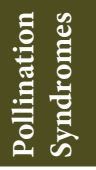 & 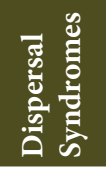 & 总 \\
\hline Anonaceae & Annona sp. 1 & $\mathrm{H}$ & E & $\mathrm{Z}$ & $\mathrm{F}$ \\
\hline Anonaceae & Annona sp. 2 & $\mathrm{H}$ & $\mathrm{E}$ & $\mathrm{Z}$ & $\mathrm{F}$ \\
\hline Apocynaceae & Aspidosperma sp. & $\mathrm{H}$ & $\mathrm{E}$ & A & $\mathrm{D}$ \\
\hline Apocynaceae & Forsteronia cordata (Müll.Arg.) Woodson & $\mathrm{H}$ & $\mathrm{E}$ & A & $\mathrm{D}$ \\
\hline Asteraceae & Mikania argyreia DC. & $\mathrm{H}$ & $\mathrm{E}$ & A Z & $\mathrm{D}$ \\
\hline Asteraceae & Mikania stipulacea Willd & $\mathrm{H}$ & $\mathrm{E}$ & A Z & $\mathrm{D}$ \\
\hline Asteraceae & Vernonanthura phaeoneura (Toledo) H.Rob. & $\mathrm{H}$ & $\mathrm{E}$ & $\mathrm{A} \mathrm{Z}$ & $\mathrm{D}$ \\
\hline Asteraceae & Vernonia diffusa Less. & $\mathrm{H}$ & $\mathrm{E}$ & A Z & $\mathrm{D}$ \\
\hline Bignoniaceae & Handroanthus heptaphyllus (Vell.) Mattos & $\mathrm{H}$ & $\mathrm{E} Z \mathrm{O}$ & A & $\mathrm{D}$ \\
\hline Bignoniaceae & Jacaranda puberula Cham. & $\mathrm{H}$ & $\mathrm{E} Z \mathrm{O}$ & A & $\mathrm{D}$ \\
\hline Combretaceae & Terminalia mameluco Pickel & $\mathrm{H}$ & $\mathrm{E} \mathrm{ZO}$ & $\mathrm{H}$ & F \\
\hline Euphorbiaceae & Alchornea sp. & $\mathrm{D}$ & $\mathrm{AF}$ & $\mathrm{Z}$ & $\mathrm{F}$ \\
\hline Euphorbiaceae & Alchornea triplinervia (Spreng.) Müll.Arg. & $\mathrm{D}$ & $\mathrm{AF}$ & $\mathrm{Z}$ & $\mathrm{F}$ \\
\hline Euphorbiaceae & Pogonophora schomburgkiana Miers ex Benth. & $\mathrm{D}$ & $\mathrm{E}$ & $\mathrm{Z}$ & $\mathrm{F}$ \\
\hline Euphorbiaceae & Croton sp. & UD & $\mathrm{E}$ & Z & F \\
\hline Euphorbiaceae & Morfo 49 & UD & $\mathrm{E}$ & AUT Z & $\mathrm{F}$ \\
\hline Fabaceae & Abarema cochliacarpos (Gomes) Barneby \& J.W.Grimes & $\mathrm{H}$ & E ZO & AUT & $\mathrm{D}$ \\
\hline Fabaceae & Andira nitida Mart. ex Benth. & UD & $\mathrm{E} Z \mathrm{O}$ & Z & $\mathrm{F}$ \\
\hline
\end{tabular}

Sexual System: $\mathrm{H}$ = Hermaphrodites; $\mathrm{M}=$ Monoecious; D = Dioecious. Pollination Syndromes: E = entomophily; $\mathrm{ZO}=$ zoophily; $\mathrm{AP}=$ anemophily. Dispersal Syndromes: $\mathrm{Z}=$ zoochoric; $\mathrm{A}=$ anemochoric; $\mathrm{AUT}=$ autochoric; HYD = hydrochoric. Fruit Types: $\mathrm{F}=$ fleshy; $\mathrm{D}=$ dry; $\mathrm{UD}=$ undetermined. 
Table 1. Continued...

\begin{tabular}{|c|c|c|c|c|c|}
\hline Family & Species & 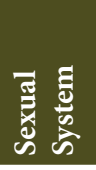 & 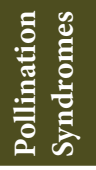 & 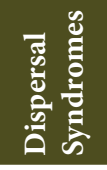 & 总 \\
\hline Fabaceae & Apuleia leiocarpa (Vogel) J.F.Macbr. & $\mathrm{H}$ & $\mathrm{E} \mathrm{ZO}$ & AUT & $\mathrm{D}$ \\
\hline Fabaceae & Cassia ferruginea (Schrad.) Schrad. ex DC & $\mathrm{H}$ & $\mathrm{E} Z \mathrm{O}$ & Z & $\mathrm{F}$ \\
\hline Fabaceae & Copaifera trapezifolia Hayne. & $\mathrm{H}$ & E ZO & AUT & $\mathrm{D}$ \\
\hline Fabaceae & Desmodium sp. & $\mathrm{H}$ & $\mathrm{E} Z \mathrm{ZO}$ & Z & $\mathrm{D}$ \\
\hline Fabaceae & Leptolobium bijugum (Spreng.) Vogel & $\mathrm{H}$ & $\mathrm{E} \mathrm{ZO}$ & HYD Z & $\mathrm{F}$ \\
\hline Fabaceae & Machaerium hirtum (Vell.) Stellfeld & $\mathrm{H}$ & $\mathrm{E} \mathrm{ZO}$ & A & $\mathrm{D}$ \\
\hline Fabaceae & Machaerium ovalifolium Glaz. ex Rudd & $\mathrm{H}$ & $\mathrm{E} Z \mathrm{O}$ & A & $\mathrm{D}$ \\
\hline Fabaceae & Machaerium sp. 1 & $\mathrm{H}$ & $\mathrm{E} Z \mathrm{O}$ & $\mathrm{A}$ & $\mathrm{D}$ \\
\hline Fabaceae & Machaerium sp. 2 & $\mathrm{H}$ & E ZO & $\mathrm{A}$ & $\mathrm{D}$ \\
\hline Fabaceae & Piptadenia sp. & $\mathrm{H}$ & E ZO & A AUT & $\mathrm{D}$ \\
\hline Fabaceae & Morfo 54 & $\mathrm{H}$ & $\mathrm{E} \mathrm{ZO}$ & AUT & $\mathrm{D}$ \\
\hline Fabaceae & Morfo 77 & $\mathrm{H}$ & $\mathrm{E} Z \mathrm{O}$ & Z & $\mathrm{D}$ \\
\hline Hypericaceae & Vismia guianensis (Aubl.) Choisy & $\mathrm{H}$ & $\mathrm{E}$ & A Z & $\mathrm{D}$ \\
\hline Lauraceae & Ocotea sp. & $\mathrm{D}$ & $\mathrm{E}$ & $\mathrm{Z}$ & $\mathrm{F}$ \\
\hline Lauraceae & Morfo 62 & UD & $\mathrm{E}$ & $\mathrm{Z}$ & $\mathrm{F}$ \\
\hline Malpighiaceae & Byrsonima sericea DC. & $\mathrm{H}$ & $\mathrm{E}$ & $\mathrm{Z}$ & $\mathrm{F}$ \\
\hline Malpighiaceae & Heteropterys sp. 2 & $\mathrm{H}$ & $\mathrm{E}$ & A & $\mathrm{D}$ \\
\hline Malpighiaceae & Mascagnia sp. & $\mathrm{H}$ & $\mathrm{E}$ & A & $\mathrm{D}$ \\
\hline Malpighiaceae & Niedenzuella acutifolia (Cav.) W. R. Anderson & $\mathrm{H}$ & $\mathrm{E}$ & A & $\mathrm{D}$ \\
\hline Malpighiaceae & Tetrapterys sp. 1 & $\mathrm{H}$ & $\mathrm{E}$ & A & $\mathrm{D}$ \\
\hline Malpighiaceae & Tetrapterys sp. 2 & $\mathrm{H}$ & $\mathrm{E}$ & A & $\mathrm{D}$ \\
\hline Malpighiaceae & Tetrapterys sp. 3 & $\mathrm{H}$ & $\mathrm{E}$ & A & $\mathrm{D}$ \\
\hline Malpighiaceae & Morfo 8 & $\mathrm{H}$ & $\mathrm{E}$ & A & $\mathrm{D}$ \\
\hline Malpighiaceae & Heteropterys sp. 1 & $\mathrm{H}$ & $\mathrm{E}$ & A & $\mathrm{D}$ \\
\hline Malvaceae & Luehea sp. & $\mathrm{H}$ & $\mathrm{E} Z \mathrm{O}$ & A & $\mathrm{D}$ \\
\hline Melastomataceae & Miconia cinnamomifolia (DC.) Naudin & $\mathrm{H}$ & $\mathrm{E}$ & $\mathrm{Z}$ & $\mathrm{F}$ \\
\hline Melastomataceae & Miconia maroana Wurdack & $\mathrm{H}$ & $\mathrm{E}$ & $\mathrm{Z}$ & $\mathrm{F}$ \\
\hline Melastomataceae & Miconia sp. & $\mathrm{H}$ & $\mathrm{E}$ & $\mathrm{Z}$ & $\mathrm{F}$ \\
\hline Moraceae & Brosimum lactescens (S.Moore) C.C.Berg & M & AP & $\mathrm{Z}$ & $\mathrm{F}$ \\
\hline Moraceae & Brosimum sp. & M & $\mathrm{AP}$ & $\mathrm{Z}$ & $\mathrm{F}$ \\
\hline Moraceae & Ficus sp. & M & AP & $\mathrm{Z}$ & $\mathrm{F}$ \\
\hline Myrsinaceae & Myrsine guianensis (Aubl.) Kuntze & $\mathrm{D}$ & $\mathrm{AP}$ & $\mathrm{Z}$ & $\mathrm{F}$ \\
\hline Myrtaceae & Eugenia sp. & $\mathrm{H}$ & $\mathrm{E} Z \mathrm{O}$ & $\mathrm{Z}$ & $\mathrm{F}$ \\
\hline Myrtaceae & Eugenia sp. & $\mathrm{H}$ & $\mathrm{E} \mathrm{ZO}$ & $\mathrm{Z}$ & $\mathrm{F}$ \\
\hline Myrtaceae & Gomidesia palustris (DC.) Kausel & $\mathrm{H}$ & E ZO & $\mathrm{Z}$ & $\mathrm{F}$ \\
\hline Myrtaceae & Marlierea tomentosa Cambess. & $\mathrm{H}$ & $\mathrm{E} Z \mathrm{O}$ & $\mathrm{Z}$ & $\mathrm{F}$ \\
\hline Myrtaceae & Myrcia multiflora (Lam.) DC. & $\mathrm{H}$ & $\mathrm{E} Z \mathrm{O}$ & $\mathrm{Z}$ & $\mathrm{F}$ \\
\hline Myrtaceae & Myrcia ovata Cambess. & $\mathrm{H}$ & $\mathrm{E} \mathrm{ZO}$ & $\mathrm{Z}$ & $\mathrm{F}$ \\
\hline Myrtaceae & Morfo 16 & $\mathrm{H}$ & $\mathrm{E} \mathrm{ZO}$ & $\mathrm{Z}$ & $\mathrm{F}$ \\
\hline Nyctaginaceae & Guapira hirsuta (Choisy) Lundell & $\mathrm{H}$ & E ZO & A & $\mathrm{D}$ \\
\hline Nyctaginaceae & Guapira sp. & $\mathrm{H}$ & $\mathrm{E} Z \mathrm{O}$ & A & $\mathrm{D}$ \\
\hline Phyllanthaceae & Hieronyma oblonga (Tul.) Müll.Arg. & $\mathrm{D}$ & $\mathrm{E}$ & $\mathrm{Z}$ & $\mathrm{F}$ \\
\hline Piperaceae & Piper sp. & $\mathrm{H}$ & $\mathrm{E}$ & $\mathrm{Z}$ & $\mathrm{F}$ \\
\hline Polygonaceae & Coccoloba tenuiflora Lindau & $\mathrm{D}$ & $\mathrm{E}$ & $\mathrm{Z}$ & $\mathrm{F}$ \\
\hline
\end{tabular}

Sexual System: H = Hermaphrodites; $\mathrm{M}=$ Monoecious; D = Dioecious. Pollination Syndromes: E = entomophily; ZO = zoophily; $\mathrm{AP}=$ anemophily. Dispersal Syndromes: $\mathrm{Z}=$ zoochoric; $\mathrm{A}=$ anemochoric; $\mathrm{AUT}=$ autochoric; $\mathrm{HYD}=$ hydrochoric. Fruit Types: $\mathrm{F}=$ fleshy; $\mathrm{D}=$ dry; $\mathrm{UD}=$ undetermined. 
Table 1. Continued...

\begin{tabular}{|c|c|c|c|c|c|}
\hline Family & Species & 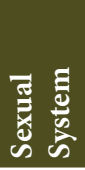 & 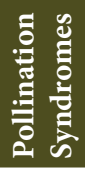 & 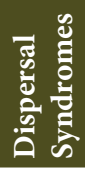 & 胥 \\
\hline Rubiaceae & Coussarea contracta (Walp.) Müll.Arg. & $\mathrm{H}$ & E ZO & $\mathrm{Z}$ & $\mathrm{F}$ \\
\hline Rubiaceae & Psychotria mapourioides DC. & $\mathrm{H}$ & E ZO & $\mathrm{Z}$ & $\mathrm{F}$ \\
\hline Rubiaceae & Psychotria sp. 1 & $\mathrm{H}$ & E ZO & $\mathrm{Z}$ & $\mathrm{F}$ \\
\hline Rubiaceae & Pysicotria carthagenensis Jacq. & $\mathrm{H}$ & E ZO & $\mathrm{Z}$ & $\mathrm{F}$ \\
\hline Rubiaceae & Pysicotria sp. 2 & $\mathrm{H}$ & E ZO & $\mathrm{Z}$ & $\mathrm{F}$ \\
\hline Rutaceae & Dictyoloma vandelianum A. Juss. & $\mathrm{H}$ & $\mathrm{E}$ & A & $\mathrm{D}$ \\
\hline Sapindaceae & Cupania sp. & M & E ZO & $\mathrm{Z}$ & $\mathrm{D}$ \\
\hline Sapindaceae & Cupania vernalis Cambess. & M & E ZO & $\mathrm{Z}$ & $\mathrm{D}$ \\
\hline Sapindaceae & Pseudima frutescens (Aubl.) Radlk. & M & $\mathrm{E} Z \mathrm{O}$ & $\mathrm{Z}$ & $\mathrm{D}$ \\
\hline Sapindaceae & Serjania sp. 1 & M & E ZO & $\mathrm{Z}$ & $\mathrm{D}$ \\
\hline Sapindaceae & Serjania sp. 2 & M & E ZO & Z & $\mathrm{D}$ \\
\hline Sapindaceae & Paullinia carpopoda Cambess. & M & E ZO & $\mathrm{Z}$ & $\mathrm{D}$ \\
\hline Solanaceae & Solanum sp. 1 & $\mathrm{H}$ & $\mathrm{E}$ & $\mathrm{Z}$ & $\mathrm{F}$ \\
\hline Solanaceae & Solanum sp. 2 & $\mathrm{H}$ & $\mathrm{E}$ & $\mathrm{Z}$ & $\mathrm{F}$ \\
\hline Trigoniaceae & Trigonia sp. & $\mathrm{H}$ & $\mathrm{E}$ & A & $\mathrm{D}$ \\
\hline Urticaceae & Cecropia glaziovii Snethl. & $\mathrm{D}$ & AP & $\mathrm{Z}$ & $\mathrm{F}$ \\
\hline Urticaceae & Cecropia hololeuca Miq. & $\mathrm{D}$ & AP & $\mathrm{Z}$ & $\mathrm{F}$ \\
\hline Urticaceae & Cecropia pachystachya Trécul & $\mathrm{D}$ & $\mathrm{AP}$ & Z & $\mathrm{F}$ \\
\hline
\end{tabular}

Sexual System: H = Hermaphrodites; $M=$ Monoecious; D = Dioecious. Pollination Syndromes: E = entomophily; ZO = zoophily; $\mathrm{AP}=$ anemophily. Dispersal Syndromes: $\mathrm{Z}=$ zoochoric; $\mathrm{A}=$ anemochoric; $\mathrm{AUT}=$ autochoric; $\mathrm{HYD}=$ hydrochoric. Fruit Types: $\mathrm{F}$ = fleshy; $\mathrm{D}=$ dry; $\mathrm{UD}=$ undetermined.

Table 2. Association between sexual systems and pollination syndromes from the study area.

\begin{tabular}{|c|c|c|c|c|c|c|c|c|c|}
\hline \multirow{2}{*}{$\begin{array}{l}\text { Sexual } \\
\text { System }\end{array}$} & \multicolumn{3}{|c|}{ Entomophily } & \multicolumn{3}{|c|}{ Zoophily } & \multicolumn{3}{|c|}{ Anemophily } \\
\hline & OF & EF & $\chi^{2}$ & OF & EF & $\chi^{2}$ & OF & EF & $\chi^{2}$ \\
\hline $\mathrm{H}$ & 57 & 23 & $0.22^{*}$ & 33 & 13 & $0.24^{*}$ & 4 & 4.3 & $3.68^{*}$ \\
\hline M & 6 & 23 & $0.49^{*}$ & 4 & 13 & $0.06^{*}$ & 4 & 4.3 & $4.14 \mathrm{~ns}$ \\
\hline $\mathrm{D}$ & 6 & 23 & $0.27^{*}$ & 2 & 13 & $1.14^{*}$ & 5 & 4.3 & $9.30 \mathrm{~ns}$ \\
\hline
\end{tabular}

$\mathrm{OF}=$ Observed Frequency; $\mathrm{EF}=$ Expected Frequency; $\chi^{2}=$ chi-square values; ns = not significant, $\mathrm{p}>0.05 ;{ }^{*}$ significant, $\mathrm{p}<0.05$. Sexual System: $\mathrm{H}$ = Hermaphrodites; $\mathrm{M}$ = Monoecious; $\mathrm{D}$ = Dioecious.

Regarding the association of sexual systems with pollination syndrome (entomophily, zoophily and anemophily), the observed and expected chi-square values were positive in most associations, with the lone exception of the unisexual systems and anemophily syndrome (Table 2). There were no exceptions for the relationship between sex systems and dispersion syndromes, and we observed that all associations were positive (Table 3).

Species with bisexual systems (hermaphrodites) are best associated with most ecological characteristics of pollination, dispersion and fruit types. This behavior can be observed in the correspondence analysis (CA) results, in which the first three axes explain $65 \%$ data variance from the Santa Marta Valley, demonstrating a strong association between the hermaphrodite system with Entomophily and Zoophily pollination syndromes, dry fruit and anemochoric dispersion. Unisex systems were also associated with ecological attributes, as the monoecious presented better relations with fruits having a succulent pericarp (fleshy fruits) and with zoochoric dispersion, and dioecious only correlated with anemophily (Figure 2). 
Table 3. Association between sexual systems and dispersal syndromes from the study area.

\begin{tabular}{|c|c|c|c|c|c|c|}
\hline \multirow{2}{*}{ Sexual System } & \multicolumn{3}{|c|}{ Biotic } & \multicolumn{3}{|c|}{ Abiotic } \\
\hline & OF & EF & $x^{2}$ & OF & EF & $x^{2}$ \\
\hline $\mathrm{H}$ & 20 & 12.3 & $1.83^{*}$ & 37 & 13.7 & $1.65^{*}$ \\
\hline M & 9 & 12.3 & $3.82^{*}$ & 1 & 13.7 & $3.45^{*}$ \\
\hline $\mathrm{D}$ & 8 & 12.3 & $1.48^{*}$ & 3 & 13.7 & $1.34^{\star}$ \\
\hline
\end{tabular}

$\mathrm{OF}=$ Observed Frequency; $\mathrm{EF}=$ Expected Frequency; $\chi^{2}=$ chi-square values. ${ }^{*}$ significant, $\mathrm{p}<0.05$. Sexual System: $\mathrm{H}=$ Hermaphrodites; $\mathrm{M}=$ Monoecious; $\mathrm{D}=$ Dioecious

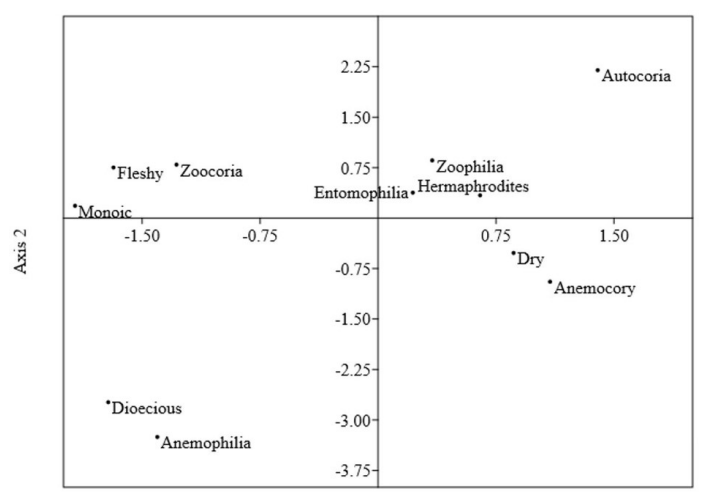

Axis 1

Figure 2. Correspondence analysis between sexual systems, pollination syndrome, dispersion and fruit type from 80 species registered in seed rain from the Santa Marta Valley, Caparaó National Park, Espírito Santo State.

\section{DISCUSSION}

The frequency distribution of sexual systems for seed rain in the Santa Marta valley generally resembles that found in tropical forests, including several phytophysiognomies. Thus, the frequencies found in this study ( $71 \%$ hermaphrodites, $13 \%$ dioecious and $11 \%$ monoecious) compare with similar studies in Costa Rica with $68 \%$ of hermaphrodite species (Bawa \& Opler, 1975), in Puerto Rico with $73 \%$ of hermaphrodites (Flores \& Schemske, 1984), 60\% and 83\% hermaphrodites from Mexico (Bullock, 1985; Machado et al., 2006, respectively). Note that $60 \%$ to $80 \%$ of the species presented in the cited studies have Hermaphroditism as the predominant sexual system in all cases.

Among the angiosperms group, the great majority of present species are hermaphrodite flowers (Henry et al., 2018) despite the occurrence of unisexual species, even though presenting a low percentage. The success of hermaphroditism in tropical forests may be related to ecological characteristics and evolutionary time of this system, because androgenic flowers (hermaphrodites) are considered primitive on the evolutionary scale of angiosperms in relation to unisexual flowers (Judd et al., 2009; Jordan \& Connallon, 2014).

Hermaphrodite flowers present low genetic variability of individuals as a negative effect due to endogamy. However, several biological mechanisms with the purpose of avoiding or reducing the development inbred fruits were developed by species over time, attributed associations with effective pollinators, and contribute to greater fruit production through the greater vigor of propagules. Studies of siring success in hermaphroditic plants often report evidence for tradeoffs between species (Hodgins \& Barrett 2008; Ellis \& Johnson 2010; Rymer et al., 2010).

A positive association with pollen agents can be understood as another contributing component to success of angiosperms in ecosystems (Van der Niet \& Johnson, 2012; Barrett, 2013). Their traits are still noticed when relating pollen syndromes with sexual systems, as only the hermaphrodite species had positive associations with all attributes analyzed in this study.

Furthermore, hermaphroditic species have strong correlation with the most environmentally friendly attributes examined in this study. These associations, especially with pollinating fauna, may be the result of mechanisms that prevent inbreeding, although the capacity of self-pollination from hermaphrodite plants were crucial for colonizing and establishing new populations around the world in the earliest times (Pannell, 2015).

Pannell (2015) affirms that the current model of evolution from dispersion and reproductive systems from species foresees associations between dispersion syndromes and crossing pollination, which could 
justify the strong association of hermaphroditism with entomophilia and zoophilia for the Santa Marta valley. The plants provide floral resources, which provide some essential necessity to pollinators and thus stimulate animals to make periodic visits so that pollen is suitably carried from one flower to another (Goldberg et al., 2010; Igic \& Busch, 2013).

Among the unisexual systems, there was statistical significance for most of the analyzed factors. However this relationship was not positive between monoecious and dioecious systems and anemophily pollination. Bawa (1980) describes this relationship stating that the wind in humid forests is not a substantial factor; hence wind pollination may be ineffective. However, there is great availability of biotic vectors, common in humid tropical forests, which can act as effective pollinating agents.

The dioecious species only presented correlation with anemophily. This is a paradox, as Bawa (1980) suggests that association of generalist pollinators with dioecious species would allow these species to easily establish, in contrast to hermaphrodites, which depend on specialized pollinators in most cases.

Dioecious species may exhibit sexual dimorphism, which is interpreted as a mechanism to increase genetic variability, reducing inbreeding in the general population (Queenborough et al., 2009). The authors postulate on increasing the occurrence of dioecious species in tropical forests, because this sexual expression occurs widely in phylogenetically distinct groups. Regarding their association with ecological factors, dioecious plants are considered to be recent on the evolutionary scale (Barrett, 2013; Igic \& Busch, 2013).

Even with a lack of associations with pollinator vectors and dispersers, dioecious species are still found with low frequency in relation to hermaphrodites. However, optimizing investment from resources in different individuals (males and females), in which male pollen dispersal invests in increasing the amount of partners and females would act in fruit production and quality of seeds, radiating the occurrence of dioecious in tropical forests (Bawa, 1980; Barrett, 2013; Queenborough et al., 2009).

Charlesworth (1993) hypothesized the evolution of dioecious angiosperms from ancestral groups of gymnosperms, which were pollinated by wind.
The author concludes that angiosperms could first be pollinated by wind due to lack of availability from attractive resources to fauna; therefore by improving the reproduction of species, these tend to specialize according to the availability of pollinators.

In this case, considering the arguments from Charlesworth (1993), the association between dioecious and anemophily in the Santa Marta valley may be related to evolutionary traits from species present in the locale. There are several possible questions on this theme, among which we can highlight that investment in availability of attractive floral resources to fauna pollinating may not be expressive at this moment in dioecious species due to a lack of time on the evolutionary scale for improvement of this resource, or cross-pollination by wind could meet the needs and demands of these species.

Different from association between sexual systems and pollinating agents when relating the forms of propagation from propagules with sexual systems for the Santa Marta valley, we observed a positive relationship between all attributes (biotic and abiotic). However, in this study monoecious species presented a correlation with dispersion (zoochory) and fleshy fruits.

In general, monoicous species present fleshy fruits with succulent pericarp to attract dispersing fauna. Du et al. (2009) indicate that the main dispersing agents in humid tropical forests with low seasonality are animals, especially mammals and birds, which could support this relationship between monoecious and zoochory. The lack of data in the literature on monoecious species makes comparative interpretations impractical in the ecological context (Matallana et al., 2005).

\section{CONCLUSION}

In this study it can be highlighted that hermaphrodite species were better associated with other reproductive traits such as pollination and dispersion syndromes, mainly related to interactions with available fauna.

Given the importance of understanding the interactions between plants and local fauna, the data generated in the present study can contribute to elaborating management and recovery programs for areas that take into account interaction aspects of plants with the local fauna. 


\section{ACKNOWLEDGEMENTS}

This study was partly financed by the Coordenação de Aperfeiçoamento de Pessoal de Nível Superior - Brasil (CAPES) - Finance Code 001. The authors thank the Conselho Nacional de Desenvolvimento Científico e Tecnológico (CNPq) - Chamada Universal - nº. 14/2011, and the Fundação de Amparo à Pesquisa e Inovação do Espírito Santo (FAPES) - Edital Universal - nº. 03/2017 for funding this research.

\section{SUBMISSION STATUS}

Received: 23 oct., 2018

Accepted: 4 dec., 2018

\section{CORRESPONDENCE TO}

\section{Monique Perini}

Instituto de Ciências Biológicas, Universidade Federal de Minas Gerais - UFMG, Av. Antônio Carlos 6627, Pampulha, CEP 31270-901, Belo Horizonte, MG, Brasil

e-mail: monique.perini@gmail.com

\section{REFERENCES}

Alvares CA, Stape JL, Sentelhas PC, Gonçalves JLM, Sparovek G. Köppen's climate classification map for Brazil. Meteorologische Zeitschrift 2013; 22(6): 711-728. http:// dx.doi.org/10.1127/0941-2948/2013/0507.

Barrett SCH. The evolution of plant reproductive systems: how often are transitions irreversible? Proceedings of the Royal Society 2013; 280(1765): 20130913. http://dx.doi. org/10.1098/rspb.2013.0913. PMid:23825207.

Bawa KS, Opler PA. Dioecism in tropical forest trees. Evolution; International Journal of Organic Evolution 1975; 29(1): 167-179. http://dx.doi.org/10.1111/j.1558-5646.1975. tb00824.x. PMid:28563295.

Bawa KS. Evolution of dioecy in flowering plants, Boston. Annual Review of Ecology and Systematics 1980; 11(1): 15-39. http://dx.doi.org/10.1146/annurev.es.11.110180.000311.

Bullock SH. Breeding systems in the flora of a tropical deciduous forest in Mexico. Biotropica 1985; 17(4): 287301. http://dx.doi.org/10.2307/2388591.

Charlesworth D. Why are unisexual flowers associated with wind pollination and unspecialized pollinators? American Naturalist 1993; 141(3): 481-490. http://dx.doi. org/10.1086/285485.
Clark DA, Brown S, Kicklighter DW, Chambers JQ, Thomlinson JR, Ni J et al. Net primary production in tropical forests: an evaluation and synthesis of existing field data. Ecological Applications 2001; 11(4): 371-384. http://dx.doi.org/10.1890/1051-0761(2001)011[0371:NP PITF]2.0.CO;2.

Du Y, Mi X, Liu X, Chen L, Ma K. Seed dispersal phenology and dispersal syndromes in a subtropical broad-leaved forest of China. Forest Ecology and Management 2009; 258(7): 1147-1152. http://dx.doi.org/10.1016/j.foreco.2009.06.004.

Ellis AG, Johnson SD. Gender differences in the effects of floral spur length manipulation on fitness in a hermaphrodite orchid. International Journal of Plant Sciences 2010; 171(9): 1010-1019. http://dx.doi.org/10.1086/656351.

Flores S, Schemske DW. Dioecy and monoecy in the flora of Puerto Rico and the Virgin Islands: ecological Correlates. The Association for Tropical Biology and Conservation 1984; 16(2): 132-139. http://dx.doi.org/10.2307/2387845.

Goldberg EE, Kohn JR, Lande R, Robertson KA, Smith $\mathrm{SA}$, Igic B. Species selection maintains self-incompatibility. Science 2010;330(6003): 493-495. http://dx.doi.org/10.1126/ science.1194513. PMid:20966249.

Goldberg EE, Otto SP, Vamosi JC, Mayrose I, Sabath N, Ming R et al. Macroevolutionary synthesis of flowering plant sexual systems. Evolution 2017; 71(4): 898-912. http://dx.doi.org/10.1111/evo.13181. PMid:28085192.

Hammer O, Harper DAT, Ryan PD. Paleontological statistics software package for education and data analysis. Palaeontologia Electronica 2001; 4(1): 1-9.

Henry IM, Akagi T, Tao R, Comai L. One hundred ways to invent the sexes: theoretical and observed paths to dioecy in plants. Annual Review of Plant Biology 2018; 69(1): 553-575. http://dx.doi.org/10.1146/annurevarplant-042817-040615. PMid:29719167.

Hodgins KA, Barrett SCH. Natural selection on floral traits through male and female function in wild populations of the heterostylous daffodil Narcissus triandrus. Evolution. 2008; 62(7): 1751-1763. http://dx.doi.org/10.1111/j.15585646.2008.00404.x. PMid:18419752.

Igic B, Busch JW. Is self-fertilization an evolutionary dead end? The New Phytologist 2013; 198(2): 386-397. http:// dx.doi.org/10.1111/nph.12182. PMid:23421594.

Jordan CY, Connallon T. Sexually antagonistic polymorphism in simultaneous hermaphrodites. Evolution 2014; 68(12): 3555-3569. http://dx.doi.org/10.1111/evo.12536. PMid:25311368.

Judd WS, Campbell CS, Kellogg EA, Stevens PF, Donoghue MJ. Sistemática vegetal: um enfoque filogenético. 3. ed. São Paulo: Artmed; 2009.

Machado IC, Lopes AV, Sazima M. Plant sexual systems and a revier of the breedings system studies in the Caatinga, a Brazilian Tropical Dry Florest. Annals of Botany 2006; 97(2): 277-287.http://dx.doi.org/10.1093/aob/mcj029. PMid:16377654. 
Matallana G, Wendt T, Araujo DSD, Scarano FR. High abundance of dioecious plants in a tropical costal vegetation. American Journal of Botany 2005; 92(9): 1513-1519. http:// dx.doi.org/10.3732/ajb.92.9.1513. PMid:21646169.

Ollerton J, Winfree R, Tarrant S. How many flowering plants are pollinated by animals? Oikos 2011; 120(3): 321326. http://dx.doi.org/10.1111/j.1600-0706.2010.18644.x.

Pannell JR. Evolution of the mating system in colonizing plants. Molecular Ecology 2015; 24(9): 2018-2037. http:// dx.doi.org/10.1111/mec.13087. PMid:25611580.

Perini M. Chuva de sementes e sistemas sexuais de espécies lenhosas em um trecho de Floresta Ombrófila Densa, Espírito Santo [dissertação]. Jerônimo Monteiro: Centro de Ciências Agrárias e Engenharias, Universidade Federal do Espírito Santo; 2016.

Peterson ML, Kay K. Mating system plasticity promotes persistence and adaptation of colonizing populations of hermaphroditic angiosperms. The American Society of Naturalists 2015; 185(1): 28-43. http://dx.doi. org/10.1086/679107. PMid:25560551.

Queenborough SA, Mazer SJ, Vamosi SM, Garwood NC, Valencia R, Freckleton RP. Seed mass, abundance and breeding system among tropical forest species: do dioecious species exhibit compensatory reproduction or abundances? Journal of Ecology 2009; 97(3): 555-566. http://dx.doi.org/10.1111/j.1365-2745.2009.01485.x.

Rivkin LR, Barrett CHS, Johnson TJM. The effects of plant sexual system and latitude on resistance to herbivores. American Journal of Botany 2018; 105(6): 977. http:// dx.doi.org/10.1002/ajb2.1098. PMid:29917233.

Rymer PD, Johnson SD, Savolainen V. Pollinator behaviour and plant speciation: can assortative mating and disruptive selection maintain distinct floral morphs in sympatry? The New Phytologist 2010; 188(2): 426-436. http://dx.doi. org/10.1111/j.1469-8137.2010.03438.x. PMid:20738786.

Thomson JD, Wilson P. Explaining evolutionary shifts between bee and hummingbird pollination: convergence, divergence, and directionality. International Journal of Plant Sciences 2008; 199(1): 23-38. http://dx.doi. org/10.1086/523361.

Van der Niet T, Johnson SD. Phylogenetic evidence for pollinator-driven diversification of angiosperms. Trends in Ecology \& Evolution 2012; 27(6): 353-361. http://dx.doi. org/10.1016/j.tree.2012.02.002. PMid:22445687. 